\title{
Problems of Police Activity in Ensuring Public Order and Public Safety
}

\author{
Dr. iur. Aleksandrs Matvejevs \\ Faculty of Social Sciences, Department of Law, \\ Daugavpils University, Latvia \\ aleksandrsmatvejevs5@inbox.lv
}

\begin{abstract}
The article addresses the issues concerning public order and public security. These two are the objects of the state administration that form separate legal institutes. The duties of the police include securing the rule of law, maintaining public order and security, preventing, detecting and investigating crimes. The police ensure safety of people and environment and prevent all violations of the law and disturbances by eliminating and investigating all such incidents. The tasks of the police are defined in the Police Act. The police cooperate with other authorities and local residents and communities in maintaining security.
\end{abstract}

Keywords: public order, public security, public place, police activity.

\section{Introduction}

The idea of public security and the need to ensure such security date back to the earliest days of civilization itself. Predominant understanding of public security today has acquired new additional elements beyond the traditional and fundamental concept of public security. Over the course of time many researchers have sought to find a clear and precise definition for public order and public security. From the very beginning of the existence of society, there has also existed crime, in one or another way of its manifestation [16].

Public order can be viewed in two senses: in a broader sense, it is a social political category that comprises varied social phenomena, including legal order, public order, public security etc.; in a narrower sense public order is a system of relations that are formed in public places, regulated by legal and other social norms and aimed at development and protection of public and private peace, human dignity and respect, and public morals. 


\section{Definition and Analysis of Threats}

The state as a historically formed entity prevented most circumstances that endangered people's life and health, their property, environment, but it was unable to solve all problems pertaining to public security. Even today people having reached a certain level of comfort and well-being are not protected from social and other threats. Moreover, in the post-industrial world the level of social, ecological and technological threats increases. Security threat is not an action, but a phenomenon, fact, event, or a person that has a potential of committing a malicious act against an object protected by the state and requires application of preventive security measures. Threat may transform into an emergency, i.e., a natural disaster, mass riots etc.

Emergency situation may be declared in case of such threat to national security, which is related to a disaster, danger thereof or threat to the critical infrastructure, if safety of the State, society, environment, economic activity or health and life of human beings is significantly endangered.

Security threat is a set of conditions and factors that endanger vital interests of individuals, society and state. Security threat is created by internal and external sources of danger and is a real or potential threat to security objects and requires action for maintenance of internal and external security. Security threat is a manifestation of danger that may cause damage to security objects. Public and other types of national security (ecological, economic, informational etc.) may be endangered by action (omission), facts, events that may lead to loss of human life, harm to health, loss of property, material damage to society and state. A threat that is transformed into a violation is an attempt to endanger security of individuals and society as well as the state protected interests. The transformation of threats results in interaction: the endangering party causes harm; the other party suffers loss or even destruction. However, a human being as an object of a harmful action is able to evaluate the events and develop tactics and system for protection against threats of varied nature, i.e., a legal protection system.

If the police protection system functions properly, an object of threat is in a state of protection that may undergo unfavourable changes. The state of protection is an absence of threats or an ability to counter threats to an object of state protection (public order, rights and freedoms of individuals, property) and prevention of emergency situations of social, technological or biological nature. The scope of security threats may differ, a threat may be global or local. The system of security threats is constantly changing, criminal threats being a major part of it.

Nowadays the state and individual security is determined by economic, political (both domestic and international) and social environment. National security of Latvia [8] is the ability of the state and the society to protect national interests and fundamental values that include independent statehood, territorial integrity and democratic order laid down in the Constitution of the Republic of Latvia [12] as well as maintenance of internal security of the state, observance of human rights, security, and protection of inhabitants. 
Threats to the state security are actions that endanger fundamental values and interests of Latvia, and situations caused by ecological, technological, and other factors that have a negative influence on national interests. Threats may manifest themselves separately in political, military, economic, informational, social, ecological, criminal etc. spheres, or be closely connected by interrelation and aggregation. Risks and threats to national interests of Latvia may result from both the international environment and the processes of national development of the state and society.

\section{Characterisation, Features, Structure and Classification of Objects of Police Protection}

The object of police protection is a notion that comprises material, spiritual and legal values to be protected by the state and its police institutions. It might be defined as follows: a social good (value) protected by the state and of vital importance to individuals, society and state, the protection of which is ensured by the system of legal measures available to the state [7].

The main subject that ensures security is the state with the assistance of legislature, executive and judiciary. However, law enforcement is complete only when the police become its participant as it performs surveillance, applies administrative and criminal procedural coercive measures, investigative activities etc. The object of police protection includes the following chain: threats - protection object - police protection. Security of an object is provided by the system of measures performed by the police. There is a number of police protection objects: human life, health, rights and freedoms, property, interests of the state and the society etc.

It has to be noted that there are fundamental categories - objects that include balanced, historically stable and evident relationships between individuals, society and the state. They are human life, rights and freedoms, property, public order and security. These objects are the supreme values of the Latvian state as their protection ensures protection of both every single element of the entirety and the entirety itself.

Each police protection object shall have the following features:

1) it exists irrespectively of human will and consciousness, is useful, benefits individuals, society and the state;

2) it needs protection against illegal actions and other forms of threat;

3 ) it is the aim of state sovereignty and its protection is an internal matter of the state;

4) it interacts with the subject of policing (police protection) that determines the status of object protection;

5 ) it is provided for in legal norms;

6) the object protection is of applied nature.

The scope of police protection objects is wide which requires their scientific classification which would facilitate research and understanding of such objects and 
determine their place, value and significance in the common system. An accurate classification and systemisation of police protection objects require detailed analysis of the structure of the object under study.

Structure is an aspect of a system for vertical examination of the police protection object from bottom to top and setting the hierarchy of the basic elements of this vertical line. The structure of the police protection object is an aspect of system invariants. A universal police protection object is a complex object as it combines various individual objects: people, property, certain territory. In its turn the universal object comprises the system of kin objects. Public order, for instance, includes order in public places with traffic such as streets, squares, public order in yards of residential areas and in protected territories.

Public security as a universal police protection object includes the following kin objects: safety of people in public places, traffic safety, fire safety, sanitary safety etc. The universal object is characterised by a large scope, universality and diversity of protection objects. The universal object includes other kin and individual ones: houses, territories, people, animals etc. Universal police protection objects are subject to the Criminal Law [8], the Law on administrative penalties for offences in the field of administration, public order, and use of the official language and other laws and regulations [4].

Kin police protection objects are also a complex object that unites numerous varied individual objects that possess kindred features and are protected by the state. For instance, traffic safety as a kin police protection object includes 'safety for everybody', safety of property (vehicles, roads, houses, trees) that may be damaged in a traffic accident. Kin objects are more realistic compared to the universal ones and form the second level in the hierarchy of police protection objects. A number of kin objects are regulated by special laws, e.g., traffic safety is regulated by the Road Traffic Law [11], fire safety - by the Fire Safety and Fire Fighting Law [3], safety of persons in public places - by the Law 'On Police' [5] etc.

Kin objects depend on individual police protection objects that have actual and strong protection. The individual police protection object is a social and legal value that is visible and is protected as an individual or applied 'set'. Individual police protection objects are concrete persons, buildings, protected territories, documents, government information etc. The individual object is a direct object as it is a value protected by police officers both in the vicinity and inside it.

Structure being an aspect of the system allows classification of phenomena both vertically and horizontally. E.g., singling out types of state security - public, national, economic etc. - is a horizontal classification of protection objects. Therefore, analysis of the structure on the basis of scale criteria determines two groups of police protection objects vertically. The first groups are complex objects which are usually wider and more general, e.g., public order includes protection of property, human rights and freedoms; universal and kin objects are complex objects. The second group is individual objects which are usually indivisible, belonging to a particular owner or representing a concrete person. 
Another criterion for division of police protection objects determining their position in a particular group is the type of object protection. According to the type of protection, the police protection objects are divided into general and special.

General police protection objects are public security and order. These objects are protected by well-known and widely used policing methods: mainly overt administrative supervision, direct administrative coercion, administrative jurisdiction, police help etc. These methods are applied by police patrol units, the Public Order Police inspectors that are in charge of a particular territory. General police protection objects are closely tied with the competence of several units of the police department. General police protection objects are stated in the Law 'On police' [5], the Road Traffic Law and other laws [11] and regulations.

Special police protection objects are objects that are protected applying more complicated methods and forms of policing that are prescribed by the Operational Activities Law [10]: investigative monitoring of correspondence, information gathering by means of special equipment, wiretapping etc. Special objects include state protection objects, protected territories, state border, special buildings, e.g., nuclear power stations etc.

Police protection objects may also be classified by the special nature of each object and under this classification all objects can be divided into natural persons and property. The first group is comprised of private persons, deputies of the parliament, deputy nominees and government officials. The second group consists of property in the wide sense of the term: buildings, land etc.

Police protection is the last link of the chain "threats - security object - police protection". The notion police protection may be defined as police activity for protection of some object (public order, government building, state border etc.) If the notion under study has such definition, a question arises whether it is equivalent to the notion of policing.

These notions are similar, but not equal. Police protection is the basis of policing and includes the most essential elements: administrative supervision and administrative coercion. These elements were the reason for the foundation of the police as an element of state administration. Moreover, the state applies them in exercising its direct functions - performing protection of the most significant objects for society and the state, including protection of the state itself. The scope of policing is wider; it includes operation of a police institution, staffing, crime intelligence, rendering help to people in emergency situations and many other tasks, although they are not always directly aimed at protection of an object or a person.

Provisions of criminal and administrative law play an important role in legal protection of objects. The protective function of the norms of criminal and administrative law is performed in many ways and by various methods. They are prohibition to perform actions with the protected objects, imposing sanctions (punishments) for offences against the protected objects; establishing legal facts that allow the law enforcement institutions (the police) to apply administrative coercive measures. Therefore, prevention of criminal and administrative offences, i.e., protection of many security objects is delegated not to 
the judicial institutions or the prosecutor's offices, but to police institutions as they are in close proximity of the objects, monitor them and, in case of an attempted crime, can prevent it or stop it on the spot.

Police protection unlike the law enforcement activity of other institutions has an applied nature. The applied nature manifests itself in police actions:

1) prevention of offences and crime in the course of patrolling or other activities;

2) identification of persons who have committed administrative or criminal offences, detention of perpetrators and taking them to the police station;

3) rendering help to persons whose life and health are endangered by perpetrators;

4) maintaining road traffic safety by controlling vehicles and pedestrians;

5) maintaining public order in public places by means of administrative supervision and applying coercive measures against persons who break the law;

6) maintaining contacts with people and gathering police information thereby instilling a sense of safety in the inhabitants of a particular territory;

7) cooperation with other police agencies (the Municipal Police) in guarding certain objects.

Police protection has its characteristic features:

1) the basis of policing for protection of security objects are monitoring (administrative supervision) and coercion. When applying administrative coercion or preventing an offence against the protection object, police institutions perform the so-called direct protection measures;

2) due to its applied nature, 24/7 operation, application of administrative coercion the police protection means play a special role in the law enforcement system of the state and its absence leads to weakness of protection or even complete lack of it despite the fact that the rest of the law enforcement elements are functioning and retain their repressive power (protective legal provisions, law enforcement institutions);

3) protection of security objects (e.g. patrolling public places) often requires application of minimum means against the potential law-breaker (oral caution, document check-up etc.) as disproportionate measures discredit themselves and have an opposite effect. Police protection effected by overt surveillance is aimed at turning the illegal disposition of the potential law-breaker into a lawabiding behavior.

\section{Analysis of Notions of Public Order and Public Security}

In respect of the activity of police institutions, legal order includes ensuring two spheres of public order and public security. The first sphere of activity is comprised of the set of activities that are performed by a police institution and its units with an aim of creating such in the particular territory that would ensure inviolability of individuals, their dignity, respect and property and enjoyment of political, economic and social rights 
and freedoms provided for in the Constitution [12]. The second sphere of activity is the maintenance of public security, i.e., protection of human life and health, material and other values of the society from the impact of natural forces, sources of high hazard, violation of technical regulations and other negative social phenomena.

The word order is usually interpreted as a willful order. This notion is rather unpopular among the liberals and increasingly popular among those supporting authoritarian power. According to this interpretation, the order in the society is based on giving orders and obeying them or on a total hierarchic structure of the society where the leaders or even a sole monarch decides what each individual shall do.

Crises in liberalism are not merely triggered by exogenous factors, such as international terrorism, wars, global economic downturns and natural disasters. They can also emerge endogenously when basic principles underpinning liberalism come adrift and, like soap bubbles, fluctuate and then burst when they come into contact with a new idea or harsh reality. One such harsh reality is insecurity of residence and the principles of liberalism that it challenges are freedom from state coercion, human emancipation from unnecessary restrictions and the equal treatment of all individuals irrespective of their place of birth and nationality.

Public order is attached to a definite territory that has limits of space and is called public place. Clause 1 of Paragraph 1 of Section 10 of the Law "On Police" provides an incomplete list of public places: "to ensure order on roads and streets, in public squares, parks, public transport, airports, ports, stations and other public places in order to guarantee safety of persons and society" [5]. The Public Entertainment and Festive Events Law explains the notion of a public event: "a festive, commemorative, sports, entertainment or recreational event planned and organised by a natural or legal person open to the public in a public place irrespectively of the ownership of the venue" [6]. The Law on Administrative Penalties for Offences in the Field of Administration, Public Order, and use of the official language: "a public place is any place which, regardless of the actual form of its use or ownership, serves for the provision of joint needs and interests of the society and which is available, for a fee or free of charge, to any natural person who is not the owner, possessor, holder, paid employee of the relevant place, or to another person whose presence in the relevant place is related to the performance of work duties" [4].

The term security is older than its constant peer public order. The notion of security was already used by the police law scholars of $18^{\text {th }}$ century and the early $19^{\text {th }}$ century; they believed that security as safeguarding the subjects (citizens) is 'the life and soul of a state'.

The nation-state is the format in which most of our central political concepts were shaped or indeed invented. On closer scrutiny, it is revealed that concepts such as community, democracy, security and identity are not only recurrently applied to the nationstate; they are also in their very meaning marked by it.

The concept of security has predominantly been used in reference to the nationstate and this without even reflecting on the distinction between state and nation: national security is the established name for the security of the state. 
While the traditional concept of security, closely identified with the military affairs of the state, is widely felt to be insufficient, attempts to articulate a 'wider' concept of security have also met with considerable reserve. The wideners have been criticised for being unable to specify a clear criterion to prevent everything becoming defined as security.

It is unclear what individual and international / global security mean. It is too easily assumed that security is a simple word the meaning of which is widely known, and thus they can immediately proceed to discussing the questions of whom, what and how. The concept of security as known from security policy has no basic meaning independent of its referent object, the state. It is naive to assume that the concept of national security (that is, state security) should be understood by detaching state and comprehending it without its security dimension (which is always inherent in the word state) and then connect this to an equally context free concept of security. The two concepts are already present in each other. If this were to be denied, both state and security would have to be reified and naturalised for them to be seen as a necessary, historical, constant entity.

Ensuring public security in normal conditions of society and the state, as well as in emergency situations is achieved through a unified state policy in the field of internal security, and therefore public security, the implementation measures of economic, political, organisational, and other measures that are aimed primarily at preventing threats to the vital interests of the state and society. Significant role in providing safety is appropriate and professional for selection of the staff [15].

The Parliamentary Assembly considers that the full exercise of human rights and fundamental freedoms, guaranteed by the European Convention on Human Rights and other national and international instruments, has as a necessary basis for the existence of a peaceful society which enjoys the advantages of public order and public security [1].

\section{Conclusions}

Some legal experts believe that public security is a public order. Others, however, explain the public security concept as more intensive and inclusive to public order, arguing that the goal of public order is provision of human security: either from other people's illegal attempts or from high-risk sources of misuse alleged negative manifestations.

In the scientific literature, the concept of public order is examined by its broader or a narrower sense. In a broader sense it is the general nature of the socio-political category, encompassing a multitude of social events, including the legal system; in a narrow sense - public security, etc. The latter sense deals with the law and other social norms regulating the system of relationships that are formed in all public areas and directed to persons of public and personal peace, human dignity and respect, public morality installation, development and safeguarding.

The analysis of the notion public security reveals its two parts:

1) conditions where there is no threat to an individual, society or state;

2) measures by the state that ensure these conditions and instill a sense of security in people. 
These elements to a certain extent determine the features and characterise public security as an object of police protection and as a definition of the notion.

Public security is based on two elements:

1) public peace when there is peace, cooperation and confidence in safety in the public realm;

2) conditions on the ability to protect where the state (the police) continuously provides public security and is ready to render help and neutralise any threats.

Thereby, in the legal reality public security is legal relations of the police where the subjects are, on the one hand, persons, society, state institutions that have a constant need of protection against crimes and other offences and, on the other hand, the state whose task is to ensure the protection stated in the legislation via competent institutions.

Thus, relations in the public security sphere are regulated by legal norms, but in the sphere of public order - by legal and social norms.

The European Code of police ethics states that the main purposes of the police in a democratic society governed by the rule of law are: (1) to maintain public tranquility and law and order in society; (2) to protect and respect the individual's fundamental rights and freedoms as enshrined, in particular, in the European Convention on Human Rights; (3) to prevent and combat crime; (4) to detect crime; (5) to provide assistance and service functions to the public [14].

The framework of the Code was provided by the European Convention on Human Rights [2] and its case law, together with a number of important Council of Europe Recommendations. It was drafted to take account of both the similarities and differences between member states in the way policing is being implemented and reformed. The Code seeks to be both a source of information and inspiration for the governments, policing practitioners and the general public of member states.

\section{Bibliography}

1. Declaration on the Police. Parliamentary Assembly of the European debate on 1 February 1979 ( $24^{\text {th }}$ Sitting of the $30^{\text {th }}$ Session) (see Doc. 4212, report of the Legal Affairs Committee). Text adopted by the Assembly on 8 May 1979 ( $2^{\text {nd }}$ Sitting of the $31^{\text {st }}$ Session). Available: http://www. assembly.coe.int/nw/xml/XRef/Xref-XML2HTML-en.asp?fileid=16101\&lang=e

2. European Convention on Human Rights. Available: https://www.echr.coe.int/Pages/home. aspx? $\mathrm{p}=$ basictexts \&c

3. Fire Safety and Fire-fighting Law of Latvia. Available: https://ikumi.lv/ta/en/en/id/68293-firesafety-and-fire-fighting-law

4. Law on administrative penalties for offences in the field of administration, public order, and use of the official language and other laws and regulations. Available: https:/likumi.lv/ta/en/ en/id/314808-law-on-administrative-penalties-for-offences-in-the-field-of-administrationpublic-order-and-use-of-the-official-language

5. Law on Police of Latvia. Available: https://likumi.lv/ta/en/en/id/67957-on-police 
Aleksandrs Matvejevs. Problems of Police Activity in Ensuring Public Order and Public Safety

6. Law on Safety of Public Entertainment and Festivity Events of Latvia. Available: https:/likumi. lv/ta/en/en/id/111963-law-on-safety-of-public-entertainment-and-festivity-events

7. Matvejevs, A. (2009). Tendencies of the evolution of the theory of policing. Riga. P. 327. ISBN 9984-689-08-5.

8. National Security Concept of Latvia. Available: https://likumi.lv/ta/en/en/id/309647-onapproval-of-the-national-security-concept

9. National Security Law of Latvia. Available: https:/likumi.lv/ta/en/en/id/14011-national-securitylaw

10. Operational Activities Law of Latvia. Available: https://likumi.lv/ta/en/en/id/57573-operationalactivities-law

11. Road Traffic Law of Latvia. Available: https://ikumi.lv/ta/en/en/id/45467-road-traffic-law

12. The Constitution of Republic of Latvia. Available: https://ikumi.lv/ta/en/en/id/57980-the-constitution-of-the-republic-of-latvia

13. The Criminal Law of Latvia. Available: https://ikumi.lv/ta/en/en/id/88966-the-criminal-law

14. The European Code of police ethics. Recommendation (2001) 10 adopted by the Committee of Ministers of the Council of Europe on 19 September 2001. Available: http://www.krim.dk/ undersider/straffesager/straffeproces/109-european_code_of_police_ethics-2001.pdf

15. Zahars, V., Stivrenieks, M. (2015). Ieslodzījuma vietu drošības aspekti. Administratīvā un kriminālā justīcija, 1(70)/2015. Rīga: Baltijas Starptautiskā akadēmija. ISSN 1407-2971.

16. Zahars, V., Stivrenieks, M. (2016). Security and safety enforcement: execution peculiarities. Journal of Security and Sustainability Issues, 6(1):71-83. DOI: http://jssidoi.org/jssi/papers/ papers/bykeyword/177 